\begin{tabular}{|c|c|c|}
\hline Dinamika Journal, Vol. 1 No. 4, 2019 \\
ISSN ONLINE : 2686-2158
\end{tabular}

\title{
PENINGKATAN KEMAMPUAN REMAJA SEBAGAI DUTA KESEHATAN DALAM UPAYA PERBAIKAN GIZI DI SMP NEGERI 1 KEMBARAN, KAB. BANYUMAS
}

\author{
Hiya Alfi Rahmah",*), Setiyowati Rahardjoº \\ ${ }^{1}$ Prodi Ilmu Gizi, Fakultas Ilmu-Ilmu Kesehatan, Universitas Jenderal Soedirman, Indonesia \\ ${ }^{2}$ Jurusan Kesehatan Masyarakat, Fakultas Ilmu-Ilmu Kesehatan, Universitas Jenderal \\ Soedirman, Indonesia \\ *Corresponding author: rahmah.hiyaalfi@gmail.com
}

Received 4 November 2019; Accepted 12 December 2019; Available online 16 December 2019

\begin{abstract}
Abstrak
Remaja putri merupakan kelompok yang berisiko menderita anemia dan mulai memperhatikan bentuk tubuh serta membatasi konsumsi makanan dan banyak pantangan terhadap makanan. Remaja merasa lebih nyaman untuk menyampaikan permasalahannya kepada teman sebaya. Tujuan kegiatan adalah meningkatkan kemampuan remaja putri terkait pengetahuan tentang anemia remaja, penyebab anemia, mengatasi body image dan perawatan kesehatan remaja. Peningkatan kemampuan remaja putri dapat dijadikan bekal remaja putri dalam memberikan pendampingan pada remaja lain dan penyuluhan di UKS (Unit Kesehatan Sekolah) maupun kegiatan lain seperti PMR (Palang Merah Remaja) dan Pramuka. Kegiatan yang dilakukan juga mendukung penyediaan prasarana berupa pojok baca UKS. Metode yang digunakan partisipatif dengan melibatkan mitra sebagai narasumber dan fasilitator. Peningkatan pengetahuan tentang pencegahan anemia diukur berdasarkan perubahan skor pretest dan posttest dengan uji statistik uji T dependen. Dari hasil pre post test pengetahuan 34 siswi, rata-rata pengetahuan pada saat pretest sebesar

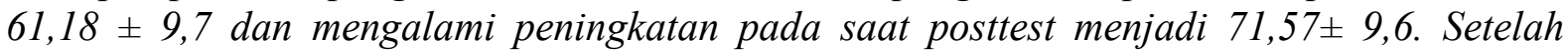
dilakukan edukasi gizi terdapat peningkatan rata- rata pengetahuan responden sebesar 16,98\%. Terdapat perbedaan pengetahuan saat pretest dan post test yang signifikan $(p<0,05)$. Terpilih 12 siswi dengan peningkatan nilai tertinggi untuk dapat mengikuti pelatihan pengukuran status gizi dengan tujuan utama memilih 3 siswi sebagai Duta Gizi Kesehatan SMPN 1 Kembaran. Duta kesehatan diharapkan mempunyai tugas sebagai penghubung antara siswa dengan pembina UKS dan tenaga puskesmas karena nantinya duta kesehatan akan selalu berada di tengah-tengah siswa, serta diharapkan dapat menjadi media transfer informasi yang tepat untuk mempercepat proses pendidikan gizi dan kesehatan kepada remaja.
\end{abstract}

Kata Kunci : Anemia, remaja putri, duta kesehatan, gizi 


\begin{abstract}
Adolescent girls are a group at risk of anemia. They also start paying attention to their body shape and restricting their food intake, as well as having a lot of food restriction. Adolescent girls feel more comfortable in communicating their issues to their peers. The aim of the activity was to improve adolescent girls' ability to learn about adolescent anemia, causes of anemia, dealing with body image and adolescent health care. Increasing adolescent girls' ability can be used as provisions for adolescent girls to provide assistance and counseling to other teenagers in the UKS and other activities such as PMR and Scouting. Activities undertaken also support the provision of infrastructure in the form of the UKS reading corner. The method used was participatory by involving partners as resource persons and facilitators. Improved knowledge of anemia prevention with dependent T-test was assessed by adjustments in the pretest and post test scores. From the pretest results of 34 students' knowledge the average knowledge was $61.18 \pm 9.7$ at the time of the pretest and increased to to $71.57 \pm 9.6$ at the post-test. Following nutrition education, the average knowledge of respondents increased by 16,98\%. There was a significant difference in knowledge at the pretest and post-test $(p<0.05)$. Twelve students with the highest number of scores were selected to participate in nutritional status assessment training with the main goal of selecting 3 students as SMPN 1 Kembaran Health Nutrition Ambassador. Health ambassadors were supposed to have a role as a liaison between students with UKS coaches and health center staff as later health ambassadors will always be among students and were expected to be the best ways of transferring knowledge to improve the nutritional and health education to adolescents.
\end{abstract}

Keywords: Anemia, adolescent girl, health nutrition ambossador

\title{
1. PENDAHULUAN
}

Remaja putri memiliki risiko sepuluh kali lebih besar untuk menderita anemia dibandingkan dengan remaja putra. Hal ini dikarenakan remaja putri mengalami menstruasi setiap bulannya dan sedang dalam masa pertumbuhan sehingga membutuhkan asupan zat besi yang lebih banyak. (Tarwoto, et al., 2010). Remaja putri biasanya sangat memperhatikan bentuk tubuh, sehingga banyak membatasi konsumsi makanan dan banyak pantangan terhadap makanan, hal ini dapat disebabkan karena kurangnya pengetahuan gizi pada remaja putri. Menurut Kuswarini (2016), ada hubungan yang signifikan antara pengetahuan dan sikap dengan angka kejadian anemia. Pengetahuan dan sikap yang tinggi terhadap pencegahan anemia akan menurunkan angka kejadian anemia.

Penelitian Kusumawati, et al. (2017) di Puskesmas I Kembaran ditemukan kejadian anemia pada remaja putri sebesar $7 \%$. Selain itu, sebanyak $72 \%$ remaja putri memiliki pengetahuan gizi kurang baik dan $56 \%$ belum pernah mendapatkan informasi mengenai anemia. Berdasarkan survey pendahuluan dan wawancara mendalam dengan kepala sekolah SMP 1 Kembaran (mitra pengabdian) diketahui bahwa sebagian besar siswi (remaja putri) mempunyai kebiasaan makan jajanan yang kurang sehat, remaja kadang mencoba untuk melakukan diet untuk terlihat langsing. Kegiatan UKS telah berjalan namun jumlah pembina masih terbatas dan ada kendala dalam melakukan konseling permasalahan kesehatan pada remaja karena ada rasa segan dari remaja untuk menyampaikan permasalahan kesehatan kepada pihak lain. Remaja menganggap guru adalah orang yang lebih tua jadi merasa tidak nyaman, takut, malu dan remaja lebih nyaman berdiskusi dan berkomunikasi dengan teman 
sebayanya. Ada beberapa remaja yang aktif mereka mencari informasi dari media internet. Untuk itu diperlukan keterampilan dari guru UKS dan siswa yang aktif mengikuti kegiatan ekstrakurikum PMR (Palang Merah Remaja) untuk mampu menggali permasalahan kesehatan remaja. Selain itu, perlu dibentuk Duta Kesehatan yang dapat membantu pembina UKS dan petugas kesehatan mencari solusi permasalah kesehatan khususnya terkait anemia remaja putri. Oleh karena itu, perlu tindak lanjut dari serangkaian kegiatan tersebut melalui PKM Penerapan IPTEKS di SMP Negeri I Kembaran, sehingga dapat meningkatkan perbaikan gizi remaja. Tujuan Pengabdian Kepada masyarakat Penerapan IPTEKS adalah meningkatkan pengetahuan dan ketrampilan remaja sebagai duta kesehatan dalam rangka Perbaikan Gizi di SMP Negeri 1 Kembaran.

\section{METODE PELAKSANAAN}

Rancangan Kegiatan PKM Penerapan Iptek dalam Peningkatan Peran Remaja Sebagai Duta Kesehatan Dalam Upaya Perbaikan Gizi Di SMP Negeri 1 Kembaran, Kecamatan Kembaran, Kabupaten Banyumas :

a. Persiapan pelaksanaan kegiatan yang akan dilakukan adalah perijinan pelaksanaan ke Bakesbanglimas dan pihak sekolah. Sosialiasasi rencana kegiatan kepada mitra kepala SMP Negeri I Kembaran dan Puskesmas I Kembaran selaku pemangku wilayah. Penentian khalayak sasaran Diskusi Terarah mengenai permasalahan agar ada pemecahan masalah dan kesepahaman tentang gizi dan kesehatan remaja dan penentuan khalayak sasaran.

b. Penyusunan media pendidikan untuk mempermudah alih teknologi dilakukan diskusi dengan pihak mitra untuk mendapakan masukan yang disesuaikan dengan kondisi sosial budaya lokasi mitra, sehingga terjadi kesesuai pendapat dan bentuk media dengan tujuan kegiatan. Pembuatan leaflet dan pengadaan Modul Pencegahan Anemia Remaja dan penyediaan alat dan bahan lainnya yang mempermudah alih teknologi serta pengadaan buku bacaan kesehatan dan gizi remaja pada UKS. Modul Pencegahan Anemia Remaja sebagi pedoman duta kesehatan mendeteksi anemia, penyebab cara penegahanya.

c. Pelaksanaan Kegiatan Pengabdian Penerapan IPTEKS dilakakan dengan edukasi gizi metode brainstorming. Peserta edukasi gizi adalah siswi SMP Negeri I Kembaran. Tujuan edukasi gizi adalah meningkatkan pengetahuan dan keterampilan remaja tentang karakteristik remaja dan permasalahannya, kebutuhan gizi remaja, anemia, faktor penyebabnya dan perilaku makan yang sehat serta body image (citra diri) remaja.

d. Pelatihan pengukuran antropometri dan penetuan status gizi untuk remaja putri dengan metode demo, praktik pengukuran BB dan TB yang benar serta skill test. Peserta 12 siswi dengan peningkatan nilai tertinggi pada edukasi gizi dengan materi: pengukuran TB dan BB yang benar, penentuan status gizi menggunakan cakram gizi.

e. Penyediaan sarana dan prasarana berupa pojok baca UKS yang diharapkan dengan dilengkapinya sarana prasarana meningkatkan kinerja UKS.

Lokasi kegiatan PKM Penerapan IPTEKS di SMP Negeri I Kembaran Kabupaten Banyumas. Partisipan dan khalayak sasaran dalam kegiatan PKM Penerapan IPTEKS ini adalah guru Pembina UKS sebagai sebagai fasilitator pemberdayaan remaja dan siswa (remaja putri) yang diambil secara purposive sampling dari siswi SMPN 1 Kembaran sebanyak 34 orang.

Bahan dan alat yang digunakan leaflet, modul, microtoise, timbangan berat badan, cakram gizi. Metode pelaksanaan kegiatan dengan menggunakan metode partisipatif dengan

H. A. Rahmah dan A. Rahardjo. 2019. Peningkatan Kemampuan Remaja Sebagai 
melibatkan mitra untuk berperan aktif sebagai fasilitator, narasumber dan mendampingi tim pengusul. Kegiatan ini juga melibatkan partisipasi aktif dari remaja putri (siswi) dan guru pembina UKS. Pelaksanakan kegiatan penerapan teknologi berupa curah pendapat (brainstorming) dan diskusi, menyusunan media pendidikan dengan melibatkan partisipasi aktif dari mitra (SMP Negeri I Kembaran).

Analisis data untuk mengetahui perubahan pengetahuan dan keterampilan pencegahan anemia diukur berdasarkan perubahan skor pretest dan posttest dengan uji statistik uji T dependen.

\section{HASIL DAN PEMBAHASAN}

a. Koordinasi dengan pihak SMP Negeri 1 Kembaran

Koordinasi dilakukan terutama dengan Kepala Sekolah, Guru-guru pelaksana UKS (Unit Kesehatan Sekolah) terkait pelaksanaan pengabdian dan juga konten materi serta media yang akan digunakan. Tujuan utama dari kegiatan pengabdian masyarakat berbasis iptek ini adalah memilih tiga orang siswi menjadi Duta gizi Kesehatan di SMP Negeri 1 Kembaran. Pemilihan dilakukan melalui dua tahap kegiatan edukasi gizi, di mana tidak hanya dilakukan pemilihan, tetapi diberikan juga materi edukasi gizi kepada siswi-siswi yang dipilih sekolah untuk dapat mentransfer materi yang didapatkan kepada teman-teman di kelas masing-masing.

\section{b. Pelaksanaan Edukasi Gizi}

Edukasi Gizi bertujuan untuk memberikan materi edukasi gizi tentang gizi untuk remaja putri. Sasaran Siswi yang dipilih secara purposive oleh sekolah sebanyak 34 siswi. Metode yang digunakan brain storming dan group discussion dengan media leaflet, modul tentang karakteristik remaja dan permasalahannya, pedoman gizi seimbang, permasalahan gizi yang terjadi pada remaja putri, anemia pada remaja putri dan faktor penyebabnya, pencegahan anemia dari segi gizi, perilaku makan sehat dan citra tubuh, kesehatan reproduksi remaja.

Karakteristik responden yang mengikuti kegiatan edukasi gizi dapat di lihat pada Tabel 1. Sedangkan untuk hasil pretest dan posttest dapat dilihat pada Tabel 2.

Tabel 1. Karakteristik responden

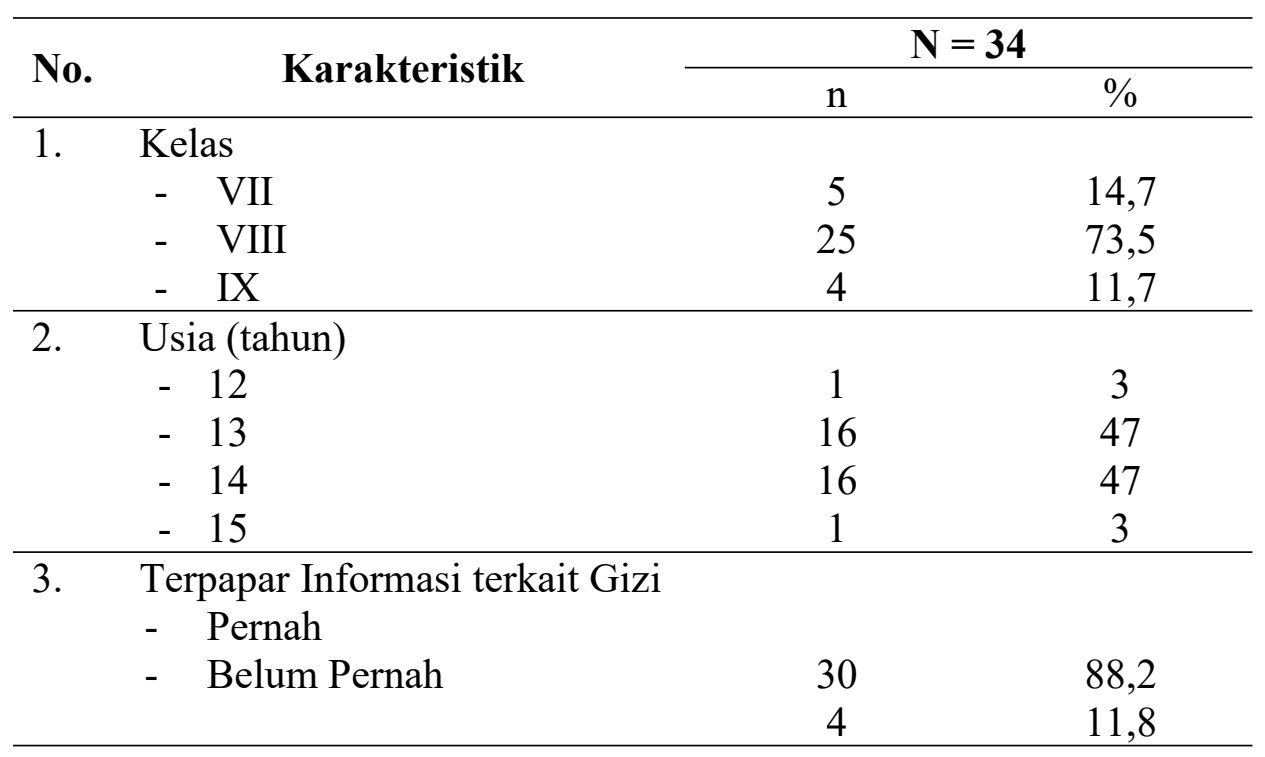


Tabel 2. Rerata skor pengetahuan remaja puti

\begin{tabular}{lcccc}
\hline Variabel & Nilai Terindah & Nilai Tertinggi & Mean \pm SD & $\begin{array}{c}\text { Peningkatan } \\
(\%)\end{array}$ \\
\hline Pengetahuan & 46,7 & 80,0 & 61,18 & 16,9 \\
- Pretest & 53,3 & 93,3 & 71,57 & \\
- Posttet & & & \\
\hline
\end{tabular}

Berdasarkan Tabel 2 dapat diketahui bahwa rata-rata pengetahuan pada saat pretest sebesar $61,18 \pm 9.7$ dan mengalami peningkatan pada saat posttest menjadi $71,57 \pm 9.6$. Hal tersebut menunjukan bahwa terdapat perbedaan pengetahuan sebelum dan sesudah diberikan intervensi edukasi gizi, peningkatan rata-rata pengetahuan responden dihitung dengan rumus: Peningkatan rata-rata pengetahuan responden:

$$
\begin{aligned}
& =\frac{\text { Skor posttest }- \text { skor pretest }}{\text { skor pretest }} \times 100 \% \\
& =\frac{71,57-61,18}{61,18} \times 100 \% \\
& =16,98 \%
\end{aligned}
$$

Berdasarkan hasil perhitungan dapat diketahui bahwa peningkatan rata- rata pengetahuan responden sebesar $16,98 \%$. Hasil penelitian ini menunjukan bahwa terdapat perbedaan pengetahuan yang signifikan $\mathrm{p}=0,000(p<0.05)$ sehingga dapat diartikan terdapat perbedaan sebelum dan sesudah dilakukan pendidikan gizi melalui metode brain storming dan group discussion serta dengan bantuan media berupa modul. Pengetahuan dipengaruhi oleh beberapa faktor yaitu pendidikan, pekerjaan, informasi, umur, lingkungan dan sosial budaya (Notoatmodjo, 2010). Hal tersebut menunjukkan bahwa pengajaran berdasarkan pengalaman memberi para siswa seperangkat situasi belajar dalam bentuk keterlibatan pengalaman sesungguhnya yang dirancang oleh guru, sehingga siswa mudah menerima informasi yang telah disampaikan.

Sesuai dengan tujuan brainstorming yaitu untuk membuat kumpulan pendapat, informasi, pengalaman semua peserta yang sama atau berbeda. Hasilnya kemudian dijadikan peta informasi (mindmap) untuk menjadi pembelajaran bersama. Kemudian akan terdapat pengelompokan-pengelompokan ide yang mempermudah peserta untuk mengelompokkan ide tersebut didalam otak masing-masing, sehingga akan terjadi mindmapping (Fitriani, 2010).

Pelatihan dapat menggunakan media. Media adalah alat yang digunakan oleh pendidik dalam menyampaiakan bahan pendidikan. Media dalam pelatihan kesehatan dapat berupa media cetak (booklet, modul, leaflet,dll) atau media elektronik (Maulana, 2012). Notoadmojdo (2010) menyatakan media pendidikan kesehatan adalah alat bantu, alat saluran (channel) untuk menyampaikan informasi kesehatan, media digunakan untuk mempermudah penerimaan pesan kesehatan bagi masyarakat.

c. Pelaksanaan Pengukuran Antropometri dan Penetuan Status Gizi untuk Remaja Putri

Tujuan pelatihan adalah memberikan materi edukasi gizi tentang Pengukuran Antropometri dan Penetuan Status Gizi untuk Remaja Putri. Sasaran adalah 12 siswi dengan peningkatan nilai tertinggi pada edukasi gizi. Metode yang digunakan adalah demo, praktik pengukuran $\mathrm{BB}$ dan $\mathrm{TB}$ yang benar serta skill test. Materi yang diberikan antara lain pengukuran TB dan BB yang benar, penentuan status gizi menggunakan cakram gizi, media

H. A. Rahmah dan A. Rahardjo. 2019. Peningkatan Kemampuan Remaja Sebagai 
yang digunakan Microtoise, Timbangan Berat Badan, Cakram Gizi. Berdasarkan hasil evaluasi edukasi tahap 1 dan 2 terpilih 3 siswi yang dipilih menjadi duta gizi kesehatan SMP Negeri 1 Kembaran.

\section{KESIMPULAN}

Kegiatan pengabdian ini dapat meningkatkan pengetahuan dan keterampilan remaja sebagai duta kesehatan dalam rangka perbaikan gizi di SMP Negeri 1 Kembaran, Kabupaten Banyumas.

\section{UCAPAN TERIMA KASIH}

Terima kasih kepada Lembaga Penelitian dan Pengadian Masyarakat Unsoed yang telah mendanai kegiatan PKM Penerapan IPTEKS dan memberikan penghargaan kepada Fakultas Ilmu-ilmu Kesehatan. Ucapan terima kasih juga disampaikan kepada SMP Negeri I Kembaran sebagai mitra kegiatan pengabdian ini.

\section{DAFTAR PUSTAKA}

Fitriani, S.2010. Promosi Kesehatan. Yogyakarta: Graha Ilmu.

Kusumawati E, Rahardjo S, Sistiarani C. 2017. Pengembangan Model Pemberdayaan Masyarakat Multifaktor dalam Upaya Menurunkan Kematian Ibu Melalui Pencegahan Anemia pada Remaja Putri di Kabupaten Banyumas. Laporan Penelitian Tahun 2017.

Kuswarini, D. I. F. 2016. Hubungan Tingkat Pengetahuan dan Sikap dengan Angka Kejadian Anemia Gizi Besi pada Mahasiswi, Prosiding Seminar Nasional Kesehatan.

Maulana, D. J. H. 2009. Promosi Kesehatan Edisi I. Jakarta: EGC.

Notoatmodjo, S. 2010. Pendidikan dan Perilaku Kesehatan, PT Rineka Cipta, Jakarta.

Tarwoto. 2010. Kesehatan Remaja: Problem dan Solusinya. Jakarta: Salemba Medika. 